\title{
Isolation of infectious hematopoietic necrosis virus from a leech (Piscicola salmositica) and a copepod (Salmincola sp.), ectoparasites of sockeye salmon Oncorhynchus nerka
}

\author{
D. Mulcahy ${ }^{1, * * *}$, D. Klaybor ${ }^{2}$, W. N. Batts ${ }^{1}$ \\ ${ }^{1}$ U.S. Fish and Wildlife Service, National Fisheries Research Center, Building 204, Naval Station Seattle, Seattle, \\ Washington 98115 , USA \\ ${ }^{2}$ U.S. Fish and Wildlife Service, Washington Cooperative Fisheries Research Unit, School of Fisheries, WH-10, University \\ of Washington, Seattle, Washington 98195, USA
}

\begin{abstract}
Infectious hematopoietic necrosis (IHN) virus was isolated from freshwater leeches Piscicola salmositica and copepods Salmincola sp. removed from the gills of spawning sockeye salmon. Oncorhynchus nerka. This is the first report of the isolation of IHN virus from an animal other than salmonid fishes. High levels of IHN virus were also found in leeches taken from the bottom gravel of the spawning area. The prevalence of IHN virus in samples of individual leeches was as high as $100 \%$ and the virus was isolated from $95 \%$ of pooled samples of copepods. The highest level of virus was $8.7 \times 10^{5}$ pfu (plaque forming units) $\mathrm{g}^{-1}$ in the copepod and $1.5 \times 10^{8} \mathrm{pfu} \mathrm{g}^{-1}$ in the leech. The level of virus in leeches removed from fish gills was sometimes higher than the level of virus in the gill tissue itself. Virus persisted for at least $16 \mathrm{~d}$ in leeches held in the laboratory without feeding. Transmission of IHN virus by leeches probably increases the infertion rate of spawning sockeye salmon.
\end{abstract}

\section{INTRODUCTION}

Infectious hematopoietic necrosis (IHN) is an acute rhabdoviral disease of salmonid fishes, particularly of sockeye salmon Oncorhynchus nerka. chinook salmon $O$. tshawytscha, and rainbow trout $O$. mykiss (formerly Salmo gairdneri); the enzootic region is the west coast of North America, and Japan. Both the disease and IHN virus have been reviewed (McAllister 1979, Pilcher \& Fryer 1980). The virus has only been isolated from adult fish at spawning and from embryos or fry dying during IHN epizootics (Mulcahy \& Bauersfeld 1983, Mulcahy et al. 1983a, Mulcahy et al. 1984). Vertical (egg-associated transmission of the virus from one generation to the next) and horizontal (waterborne transmission of the virus from fish-to-fish) are thought to account for all infections (Amend 1975, Mulcahy et al. 1983c). IHN

\footnotetext{
- Addressee for correspondence

- Present address: University of Wisconsin, School of Veterinary Medicine, 2015 Linden Drive, Madison, Wisconsin 53706, USA
}

virus has not been previously isolated from animals other than salmonid fishes.

Ectoparasites have been implicated as possible vectors for other fish viruses (Cusack \& Cone 1986). Rhabdovirus carpio was isolated from Argulus foliaceus parasitizing carp Cyprinus carpio suffering from spring viremia (Pfeil-Putzien \& Baath 1978). Ahne (1978, 1985) and Pfeil-Putzien (1978) directly demonstrated transmission of $R$. carpio by A. foliaceus. The leech Piscicola geometra was also shown to be a vector for $R$. carpio (Ahne 1985). Moewus-Kobb (1965) infected seahorses Hippocampus erectus, an atypical host, with infectious pancreatic necrosis virus by feeding them a parasitic ciliate, Miamiensis avidus, carrying the virus - a ciliate in which the virus apparently did not replicate. Recently, Halder \& Ahne (1988) suggested that freshwater crayfish Astacus astacus could serve as a vector for infectious pancreatic necrosis virus.

We report the isolation of IHN virus from 2 external parasites of salmon: the salmon leech Piscicola salmositica and a gill copepod, Salmincola sp. The virus was isolated from leeches collected from stream gravel 
and from leeches and copepods removed from spawning sockeye salmon.

\section{MATERIALS AND METHODS}

Study site. The sockeye salmon population in the Cedar River, a tributary to Lake Washington, Seattle, USA, was used in this study. This population has a high annual prevalence of IHN virus in spawning adults (Mulcahy et al. 1983b). All samples were collected in fall 1985 and 1986.

Fish and parasites. Fish were collected by seining. Leeches were removed with forceps from the gills and fins, and copepods were collected by pulling them off the gills with forceps. Leeches were also collected from the streambed gravel by hand.

Parasites were taken from sockeye salmon from which cavity ('ovarian') fluid (CF) or spleen samples had been collected for virus assay (Mulcahy et al. 1984, Mulcahy et al. 1987). The CF and spleen samples were obtained from female and male fish, respectively. Gill tissues were also taken from fish of both sexes to test for virus infections resulting from transmission of the virus by the parasite or waterborne route (Mulcahy et al. 1983c). The spawning condition (ripe or spent) of female fish was determined by the presence or absence of egg masses in the abdomen. CF samples were collected from female fish by squeezing eggs and fluid from the vent into a paper cup, and decanting the fluid into a tube. Samples of gill and spleen tissues were taken with forceps and scissors, using sterile tools for each sample.

A separate experiment was performed to compare the level of virus in gill, spleen, kidney, CF, blood, and leech. Samples of organs and body fluids, and up to 5 leeches from each fish, were taken from 28 spent female sockeye salmon. When possible, leeches were obtained from gills.

Virus assay. Leeches and copepods were homogenized using the blunt end of a steel rod. Copepods from each fish were processed in groups of up to 12 , but leeches were homogenized individually. Tissues and body fluids were processed as described by Mulcahy et al. (1982). Detection and quantitation of IHN virus was performed using the plaque assay (Burke \& Mulcahy 1980) as modified by Mulcahy et al. (1982), using the epithelioma papulosum cyprini cell line (Fijan et al. 1983). The mean virus titer and the standard error of the mean were calculated as pfu $\mathrm{ml}^{-1}$ or pf $\mathrm{g}^{-1}$ following $\log _{10}$ transformation of the individual titers.

Virus neutralization. The identity of the virus isolated from leeches was confirmed by serum neutralization tests using antiserum produced in rabbits against the Cedar River sockeye salmon isolate of IHN virus (Mulcahy \& Wood 1986).
Persistence of IHN virus in leeches. Leeches were collected from sockeye salmon in the Cedar River and transported to the laboratory where they were placed in tanks with running water at $10^{\circ} \mathrm{C}$. Cover was provided by large rocks, and they were maintained without feeding. Periodically, live leeches were removed and individually sampled for IHN virus. Dead leeches were not assayed for virus due to their poor condition.

\section{RESULTS}

\section{Collection of leeches and copepods}

Leeches were readily observed on the bodies and gills of sockeye salmon as fish were captured. They were 2 to $3 \mathrm{~cm}$ long, dark brown to black, with obvious anterior and posterior suckers, and were identified as Piscicola salmositica. As many as 70 leeches were attached to a single fish, generally on the gills and fins. Rarely was a fish found without leeches. Many leeches were observed dropping from fish being lifted from the seine. Most leeches would detach from a fish that was killed and left on a gravel bank for more than a few minutes. Typically, only 2 or 3 gill copepods, which attach to fish hosts after the returning adults enter fresh water, were found on the fish. Fish without gill copepods were common. The copepod was not identified beyond the genus Salmincola.

Leeches could be readily collected from the streambed gravel in the area of active salmon spawning, with as many as 5 to 10 leeches found in several handfuls of gravel. Leeches were rare or absent in areas of the river in which salmon were not spawning. Although some leeches collected from gravel showed evidence of earlier blood meals, most did not.

\section{Identification of IHN virus}

Based on plaque morphology and cytopathic effects in cell cultures, the virus isolates from leeches and copepods were indistinguishable from the IHN virus customarily isolated from the sockeye salmon in the Cedar River population. The isolates from leeches were also neutralized by antiserum produced against the Cedar River sockeye salmon IHN virus strain.

\section{IHN virus prevalence and titer in ectoparasites}

A total of 18 out of 19 pools of copepods taken from the gills of sockeye salmon of both sexes contained IHN virus, the median titer being $7.8 \times 10^{3} \mathrm{pfu}^{-1}$. Virus 
titers ranged from $2.5 \times 10^{1}$ to $8.7 \times 10^{5} \mathrm{pfu}^{-1}$. Virus infections of the source fish were not determined.

Leeches were collected from spawning sockeye salmon and from gravel taken from the spawning area over a $28 \mathrm{~d}$ period in 1985. In addition, leeches were also taken from the gravel $72 \mathrm{~d}$ following the original sampling. Detection of IHN virus in individual leeches was variable, especially in those collected from gravel (Table 1). Over the first $28 \mathrm{~d}$ sampling, leeches taken from fish had a higher overall prevalence (82\%) than did leeches taken from streambed gravel (57\%), but the mean titers of leeches from the 2 sources were identical $\left(1.3 \times 10^{3} \mathrm{pfu}^{-1}\right)$. The prevalence of virus in leeches obtained from gravel on Day 72 , when few fish remained on the spawning grounds, had declined to $20 \%$. There was no apparent relationship between the evidence of a recent blood meal in leeches and the presence and titer of IHN virus.

\section{Persistence of IHN virus in leeches held in the laboratory}

To determine the persistence of IHN virus in leeches, 2 groups of leeches, collected on different days from the streambed gravel, were held in the laboratory without feeding and sampled periodically for $16 \mathrm{~d}$ (Group A) or for $13 \mathrm{~d}$ (Group B). In both groups, leeches began to die immediately, and mortality continued throughout the holding period. Dead leeches quickly became covered with fungus and were not assayed for virus. On the first day of sampling, the IHN virus infection rate was $81 \%$ in Group A and $20 \%$ in Group B (Table 2). The infection rate varied greatly over the holding period in Group A but was relatively constant in Group B. The mean titers in Group B leeches began and remained higher than the mean titers in Group $A$ leeches (Table 2). The mean titers in both groups increased with time, perhaps due to replication of IHN virus in leeches.
Table 1. The prevalence over time of IHN virus in leeches Piscicola salmositica taken from the gills of spawning sockeye salmon Oncorhynchus nerka or from the stream bottom gravel in a spawning area. The first day of sampling was 16 October 1985. N: no. tested; P: \% positive; SEM: standard error of the mean

\begin{tabular}{|lrrrrr|}
\hline \multirow{2}{*}{ Source } & Day & N & P & \multicolumn{2}{c|}{$\begin{array}{c}\text { Mean titer } \\
\text { pfu g }\end{array}$} \\
\hline Fish & & & & SEM \\
& 1 & 5 & 40 & $1.7 \times 10^{1}$ & $3.31 \times 10^{\circ}$ \\
& 9 & 9 & 100 & $2.2 \times 10^{3}$ & $2.98 \times 10^{0}$ \\
& 15 & 9 & 89 & $7.1 \times 10^{1}$ & $2.29 \times 10^{\circ}$ \\
& 17 & 25 & 88 & $3.5 \times 10^{3}$ & $1.95 \times 10^{0}$ \\
& 21 & 20 & 90 & $1.6 \times 10^{3}$ & $2.73 \times 10^{\circ}$ \\
& 28 & 7 & 86 & $2.6 \times 10^{3}$ & $7.70 \times 10^{0}$ \\
Gravel & 1 & 5 & 80 & $3.4 \times 10^{3}$ & $8.18 \times 10^{\circ}$ \\
& 4 & 15 & 53 & $1.3 \times 10^{4}$ & $6.02 \times 10^{0}$ \\
& 9 & 3 & 33 & $1.9 \times 10^{2}$ & 0 \\
& 15 & 5 & 100 & $7.6 \times 10^{2}$ & $6.40 \times 10^{\circ}$ \\
& 17 & 25 & 64 & $9.8 \times 10^{3}$ & $2.81 \times 10^{\circ}$ \\
& 21 & 20 & 30 & $2.0 \times 10^{4}$ & $7.62 \times 10^{\circ}$ \\
& 28 & 21 & 81 & $4.0 \times 10^{1}$ & $1.78 \times 10^{0}$ \\
& 72 & 20 & 20 & $1.1 \times 10^{3}$ & $9.17 \times 10^{\circ}$ \\
& & & & & \\
\hline
\end{tabular}

\section{Comparison of IHN virus prevalence and titer in ectoparasites and host fish tissues}

The presence and titer of IHN virus in individual leeches and pools of copepods were compared to the occurrence of virus in gill and spleen samples from the same host fish in 6 males and in gill tissue and CF from 7 ripe and 5 spent female host fish (Table 3 ). The IHN virus infection rate was $71 \%$ in ripe females, and $100 \%$ in both spent females and in males, as indicated by testing CF and spleen samples. None of the copepod pools had a virus titer higher than the host's gill tissue. Because of the strong attachment of copepods to their host, gill tissue was frequently torn away when the copepod was removed and the tissue was included in the sample. In general, virus titers in individual leeches were equal to, or lower than, the virus titers of the

Table 2. Persistence of IHN virus in two groups of leeches held in the laboratory without feeding. Leeches that died were not sampled. Abbreviations as in Table 1

\begin{tabular}{|c|c|c|c|c|c|c|c|c|}
\hline \multirow[t]{3}{*}{ Days } & \multicolumn{4}{|c|}{ Group A } & \multicolumn{4}{|c|}{ Group B } \\
\hline & \multirow[t]{2}{*}{$N$} & \multirow[t]{2}{*}{$\mathrm{P}$} & \multicolumn{2}{|c|}{ Mean titer } & \multirow[t]{2}{*}{$N$} & \multirow[t]{2}{*}{$\mathrm{P}$} & \multicolumn{2}{|c|}{ Mean titer } \\
\hline & & & $\left(p f u g^{-1}\right)$ & SEM & & & $\left(p f u g^{-1}\right)$ & SEM \\
\hline 0 & 20 & 81 & $4.0 \times 10^{1}$ & $1.8 \times 10^{0}$ & 20 & 20 & $1.1 \times 10^{3}$ & $9.1 \times 10^{0}$ \\
\hline 6 & & & Not done & & 10 & 30 & $1.2 \times 10^{5}$ & $2.3 \times 10^{0}$ \\
\hline 7 & 18 & 11 & $2.5 \times 10^{3}$ & $1.9 \times 10^{1}$ & 5 & 20 & $2.5 \times 10^{1}$ & 0 \\
\hline 9 & 10 & 60 & $5.4 \times 10^{3}$ & $3.5 \times 10^{0}$ & \multicolumn{4}{|c|}{ Not done } \\
\hline 13 & & & Not done & & 10 & 30 & $4.5 \times 10^{4}$ & $1.6 \times 10^{0}$ \\
\hline 16 & 23 & 39 & $6.5 \times 10^{3}$ & $5.8 \times 10^{0}$ & & & & \\
\hline
\end{tabular}


Table 3. IHN virus titers (pfu g $\mathrm{g}^{-1}$ or pfu $\mathrm{ml}^{-1}$ ) for 18 sockeye salmon spawners and for samples of copepods (pooled) and leeches (individual) carried by these fish. Fish are arranged in order of virus titers obtained from gills. CF and spleen samples were obtained from female and male fish respectively; gill samples were from both sexes. -: No sample available for testing

\begin{tabular}{|c|c|c|c|c|c|c|c|}
\hline \multicolumn{3}{|c|}{ Fish } & \multicolumn{4}{|c|}{ Parasites } & \\
\hline CF or Spleens & Gills & Copepods & & & Leeches & & \\
\hline \multicolumn{8}{|l|}{ Ripe Ímaies } \\
\hline 0 & 0 & 0 & 0 & 0 & $4.8 \times 10^{6}$ & - & - \\
\hline 0 & $9.5 \times 10^{1}$ & - & $1.3 \times 10^{2}$ & - & - & - & - \\
\hline $1.4 \times 10^{2}$ & $3.1 \times 10^{4}$ & $5.0 \times 10^{0}$ & $5.1 \times 10^{2}$ & $7.3 \times 10^{2}$ & $2.5 \times 10^{6}$ & - & - \\
\hline $1.0 \times 10^{1}$ & $3.4 \times 10^{4}$ & $1.6 \times 10^{4}$ & $4.0 \times 10^{1}$ & $6.0 \times 10^{1}$ & $9.0 \times 10^{1}$ & $1.4 \times 10^{2}$ & $4.9 \times 10^{2}$ \\
\hline $3.6 \times 10^{6}$ & $1.2 \times 10^{5}$ & $1.9 \times 10^{2}$ & $2.0 \times 10^{1}$ & $4.0 \times 10^{1}$ & $1.1 \times 10^{2}$ & - & - \\
\hline $7.4 \times 10^{\prime}$ & $1.6 \times 10^{5}$ & - & $3.4 \times 10^{4}$ & $5.5 \times 10^{4}$ & $1.1 \times 10^{5}$ & $1.5 \times 10^{5}$ & $1.7 \times 10^{5}$ \\
\hline $9.3 \times 10^{6}$ & $3.7 \times 10^{5}$ & - & $1.5 \times 10^{1}$ & $5.9 \times 10^{2}$ & $1.8 \times 10^{2}$ & $3.1 \times 10^{5}$ & $5.1 \times 10^{5}$ \\
\hline \multicolumn{8}{|l|}{ Spent females } \\
\hline $6.4 \times 10^{6}$ & $3.8 \times 10^{5}$ & $2.0 \times 10^{4}$ & 0 & $1.0 \times 10^{2}$ & $1.5 \times 10^{2}$ & $1.9 \times 10^{2}$ & $3.1 \times 10^{2}$ \\
\hline $3.4 \times 10^{7}$ & $5.7 \times 10^{3}$ & $1.9 \times 10^{5}$ & $1.7 \times 10^{4}$ & $3.0 \times 10^{4}$ & $3.0 \times 10^{4}$ & $7.7 \times 10^{4}$ & $1.6 \times 10^{5}$ \\
\hline $2.2 \times 10^{4}$ & $6.5 \times 10^{5}$ & $2.1 \times 10^{2}$ & $3.5 \times 10^{1}$ & $9.5 \times 10^{3}$ & $2.2 \times 10^{4}$ & - & - \\
\hline $3.9 \times 10^{3}$ & $1.9 \times 10^{6}$ & $2.5 \times 10^{4}$ & $1.2 \times 10^{2}$ & $1.3 \times 10^{2}$ & $2.6 \times 10^{2}$ & $4.0 \times 10^{2}$ & $1.3 \times 10^{5}$ \\
\hline $8.2 \times 10^{3}$ & $4.1 \times 10^{6}$ & $1.9 \times 10^{5}$ & $1.9 \times 10^{2}$ & $4.5 \times 10^{2}$ & $3.5 \times 10^{4}$ & $1.9 \times 10^{5}$ & - \\
\hline \multicolumn{8}{|l|}{ Males } \\
\hline $2.0 \times 10^{1}$ & $1.6 \times 10^{2}$ & 0 & 0 & $5.0 \times 10^{0}$ & $2.0 \times 10^{1}$ & - & - \\
\hline $3.1 \times 10^{5}$ & $2.4 \times 10^{5}$ & $1.2 \times 10^{4}$ & $1.3 \times 10^{2}$ & $1.9 \times 10^{2}$ & - & - & - \\
\hline $6.0 \times 10^{4}$ & $2.7 \times 10^{5}$ & $6.5 \times 1.0^{4}$ & $8.0 \times 10^{1}$ & $1.5 \times 10^{2}$ & $1.5 \times 10^{4}$ & $1.5 \times 10^{4}$ & $2.4 \times 10^{4}$ \\
\hline $4.1 \times 10^{6}$ & $4.7 \times 10^{5}$ & $2.7 \times 10^{5}$ & $1.1 \times 10^{2}$ & $3.1 \times 10^{2}$ & $1.5 \times 10^{4}$ & - & - \\
\hline $5.5 \times 10^{6}$ & $2.3 \times 10^{6}$ & $1.3 \times 10^{5}$ & 0 & 0 & $1.0 \times 10^{1}$ & $7.0 \times 10^{1}$ & $1.6 \times 10^{2}$ \\
\hline $6.5 \times 10^{4}$ & $2.7 \times 10^{6}$ & $3.2 \times 10^{5}$ & $1.5 \times 10^{2}$ & $1.9 \times 10^{2}$ & $4.0 \times 10^{3}$ & $5.5 \times 10^{6}$ & $1.5 \times 10^{7}$ \\
\hline
\end{tabular}

corresponding gill tissues. A few leeches had titers higher than the gill tissues. One leech, from a male fish, had a titer of $1.5 \times 10^{7} \mathrm{pfu}^{-1}$. Although this was the highest titer obtained from a leech in this study, this value was slightly less than one $\log _{10}$ greater than the gill virus titer (Table 3 ). Some leeches without virus were found on fish with virus present in their gill tissue at titers up to $10^{6} \mathrm{pfu}^{-1}$. Two leeches with IHN virus were taken from two ripe females with negative CF. One of these leeches had a titer of $4.8 \times 10^{6} \mathrm{pfu} \mathrm{g}^{-1}$ and was taken from a fish which had no virus present in the gill tissue.

The fish blood the leeches feed on may be a source of IHN virus in addition to gill tissues. In a separate study, gills, spleen, kidneys, blood, and CF samples and up to 5 leeches were taken from 28 ripe and spent female sockeye salmon and tested for IHN virus. The virus titers obtained from samples from a representative group of 12 spent female sockeye salmon are shown in Table 4. All tissue and CF samples were positive, except for kidne: and spleen samples from one fish. Only $5 \%$ of the 134 leeches tested and $46 \%$ of blood samples had no detectable IHN virus. Of the 127 leeches with IHN virus, the distribution of virus titers over $\log _{10}$ intervals was: $0 \%$ at $10^{1}, 23 \%$ at $10^{2}, 34 \%$ at $10^{3}, 22 \%$ at $10^{4}, 12 \%$ at $10^{5}$, and $9 \%$ at $10^{6}$ pfu $\mathrm{g}^{-1}$. Individual fish could be found with virus titers in leeches that were higher or lower than the titers in blood or gills. The titers in leeches were generally lower than those in gill tissues and higher than those in blood. Virus titers were generally very high in gills and very low in the blood of sockeye salmon (Mulcahy et al. $1982,1984)$.

\section{DISCUSSION}

The epizootiological model of IHN virus in salmon is based on the absence of either a reservoir of infection or a vector. The only known source of infectious virus is the fish itself. In this model, some of the survivors of an epizootic become carriers of virus which is not detectable for most of the life of the host. After the salmon return from the ocean to spawn, the virus suddenly reappears as the fish are ripening, to be vertically transmitted with the eggs of some females (Mulcahy et al. 1984, Mulcahy \& Pascho 1985). The virus is isolated only from dead eggs or from fry suffering an epizootic (Mulcahy et al. 1983a, Mulcahy \& Pascho 1985). In this model, a lifelong carrier state and vertical transmission of the virus are essential to the persistence of infection in the host population.

Our finding, that leeches harbored IHN virus, may permit a modification of the IHN model. We did not show that IHN virus replicated in the leech and no microscopic histopathology suggestive of IHN virus 
Table 4. IHN virus titers (pfu g $\mathrm{g}^{-1}$ or pfu $\mathrm{ml}^{-1}$ ) in tissues and fluids of $12 \mathrm{IHN}$ virus-positive, spent female sockeye salmon, and in 5 randomly selected leeches they harbored. Data are arranged by increasing virus titers in gill tissue samples

\begin{tabular}{|c|c|c|c|c|c|c|c|c|c|}
\hline \multicolumn{5}{|c|}{ Tissue or fluid } & \multicolumn{5}{|c|}{ Leeches } \\
\hline Gill & Spleen & Kidney & $\mathrm{CF}$ & Blood & 1 & 2 & 3 & 4 & 5 \\
\hline $5.0 \times 10^{1}$ & 0 & 0 & $8.0 \times 10^{1}$ & 0 & 0 & 0 & $1.0 \times 10^{2}$ & $1.0 \times 10^{2}$ & $1.2 \times 10^{5}$ \\
\hline $1.0 \times 10^{2}$ & $1.1 \times 10^{4}$ & $4.8 \times 10^{3}$ & $2.1 \times 10^{2}$ & $3.0 \times 10^{2}$ & 0 & $1.0 \times 10^{3}$ & $3.4 \times 10^{3}$ & $3.6 \times 10^{3}$ & $1.2 \times 10^{4}$ \\
\hline $8.5 \times 10^{2}$ & $1.5 \times 10^{2}$ & $1.5 \times 10^{2}$ & $2.2 \times 10^{3}$ & 0 & $2.0 \times 10^{2}$ & $4.0 \times 10^{2}$ & $3.9 \times 10^{3}$ & $4.4 \times 10^{3}$ & $4.4 \times 10^{4}$ \\
\hline $1.4 \times 10^{3}$ & $2.0 \times 10^{4}$ & $7.0 \times 10^{3}$ & $7.2 \times 10^{3}$ & $1.7 \times 10^{3}$ & $1.0 \times 10^{2}$ & $2.0 \times 10^{2}$ & $5.0 \times 10^{2}$ & $1.5 \times 10^{3}$ & $4.0 \times 10^{3}$ \\
\hline $1.8 \times 10^{3}$ & $2.1 \times 10^{3}$ & $4.4 \times 10^{3}$ & $3.5 \times 10^{3}$ & $4.0 \times 10^{2}$ & $2.0 \times 10^{2}$ & $7.0 \times 10^{2}$ & $1.3 \times 10^{3}$ & $3.6 \times 10^{3}$ & $2.8 \times 10^{4}$ \\
\hline $3.1 \times 10^{4}$ & $9.6 \times 10^{3}$ & $5.5 \times 10^{2}$ & $2.9 \times 10^{4}$ & 0 & $1.0 \times 10^{2}$ & $2.0 \times 10^{2}$ & $1.3 \times 10^{3}$ & $1.4 \times 10^{3}$ & $6.2 \times 10^{3}$ \\
\hline $3.2 \times 10^{4}$ & $1.8 \times 10^{3}$ & $2.8 \times 10^{4}$ & $5.0 \times 10^{0}$ & $2.0 \times 10^{2}$ & $4.0 \times 10^{2}$ & $7.0 \times 10^{2}$ & $1.3 \times 10^{3}$ & $1.7 \times 10^{3}$ & $7.8 \times 10^{3}$ \\
\hline $1.3 \times 10^{5}$ & $3.4 \times 10^{6}$ & $5.4 \times 10^{4}$ & $6.1 \times 10^{6}$ & 0 & $2.0 \times 10^{2}$ & $5.0 \times 10^{2}$ & $7.0 \times 10^{2}$ & $8.0 \times 10^{2}$ & $1.5 \times 10^{3}$ \\
\hline $2.6 \times 10^{5}$ & $3.5 \times 10^{2}$ & $4.5 \times 10^{2}$ & $5.0 \times 10^{0}$ & 0 & $1.0 \times 10^{2}$ & $1.5 \times 10^{4}$ & $1.5 \times 10^{3}$ & $2.0 \times 10^{2}$ & $4.0 \times 10^{6}$ \\
\hline $1.1 \times 10^{6}$ & $3.2 \times 10^{7}$ & $6.4 \times 10^{7}$ & $3.0 \times 10^{8}$ & $8.3 \times 10^{5}$ & $3.1 \times 10^{5}$ & $5.0 \times 10^{5}$ & $6.1 \times 10^{5}$ & $6.4 \times 10^{5}$ & $9.7 \times 10^{5}$ \\
\hline $8.3 \times 10^{6}$ & $2.2 \times 10^{7}$ & $3.3 \times 10^{6}$ & $2.0 \times 10^{8}$ & $2.0 \times 10^{2}$ & $3.8 \times 10^{5}$ & $4.9 \times 10^{5}$ & $1.2 \times 10^{6}$ & $1.5 \times 10^{6}$ & $1.5 \times 10^{6}$ \\
\hline $1.5 \times 10^{7}$ & $6.1 \times 10^{7}$ & $3.4 \times 10^{6}$ & $6.0 \times 10^{8}$ & $1.0 \times 10^{2}$ & $3.0 \times 10^{2}$ & $5.0 \times 10^{2}$ & $1.7 \times 10^{5}$ & $8.9 \times 10^{5}$ & $1.3 \times 10^{6}$ \\
\hline
\end{tabular}

replication was seen in leeches. However, high levels of virus were found in some leeches which did not show the remains of a blood meal and the mean virus titer in non-feeding leeches held in the laboratory generally increased over time. This suggests that the virus may actually replicate in leeches. Further evidence that virus may be replicating in leeches comes from the finding that higher titers of IHN virus were found in some leeches than in the gill tissues of the host fish. We did not identify the cause of death of leeches held in the laboratory, some of which may have died as a result of the replication of IHN virus.

It seems possible that leeches serve as vectors for IHN virus among the spawning adult salmon by moving from fish-to-fish to feed. The fish-to-fish movement of leeches may explain why positive leeches were found on negative host fish and why leeches with high virus titers were found on host fish with low virus titers. The IHN virus infection rate among spawning salmon in the Cedar River generally increases with time (Mulcahy et al. 1984). This increase may be due to the natural reappearance of the virus from its carrier state, or due to waterborne (Mulcahy et al. 1983c) or leech-transmitted virus from infected adult salmon.

Some individual leeches of this species may overwinter (Becker 1964). Such individuals could represent a reservoir of infection of IHN virus if they maintained the virus until they fed on either resident fishes or the newly hatched salmon alevins. They could conceivably therefore, be a source of virus for an epizootic. Some leeches held in the laboratory laid cocoons before dying. We were not able to recover IHN virus from the cocoons (Mulcahy unpubl.) but it is possible that the amount of virus present in the tiny cocoons was below the detection limits of our assay.
Acknowledgements. This work was supported by the Bonneville Power Administration Interagency Agreement DE-A179$82 B$ P36990 and the U.S. Fish and Wildlife Service. Leeches were identified by C. D. Becker, Battelle Northwest, Richland, WA 99352, USA. W. Y Yasutake, National Fisheries Research Center, Bldg. 204, Naval Station Seattle, Seattle, WA 98115 , USA examined the leeches for histopathology.

\section{LITERATURE CITED}

Ahne, W. (1978). Untersuchungsergebnisse über die akute Form der Bauchwassersucht (Frehlingsviraemie) der Karpfen. Fischwirt 28: 46-47

Ahne, W. (1985). Argulus foliaceus L. and Pisicola geometra L. as mechanical vectors of spring viremia of carp virus (SVCV). J. Fish Dis. 8: 241-242

Amend, D. F. (1975). Detection and transmission of infectious hematopoietic necrosis virus in rainbow trout. J. Wild]. Dis. 11: $471-478$

Becker, C. D. (1964). The parasite-vector-host relationship of the hemoflagellate, Cryptobia salmonsitica Katz, the leech, Piscicola salmositica Meyer, and certain teleosts. Ph.D dissertation, University of Washington, Seattle

Burke, J. A., Mulcahy, D. (1980). Plaquing procedure for infectious hematopoietic necrosis virus. Appl. envirl Microbiol. 39: 872-876

Cusack, R., Cone, D. K. (1986). A review of parasites as vectors of viral and bacterial diseases of fish. J. Fish Dis. 9: 169-171

Fijan, N., Sulimanovic, D., Bearzotti, M., Muzinic, D., Zwillenberg, L. O., Chilmonczyk, S., Vautherot, J. F., de Kinkelin, P. (1983). Some properties of the epithelioma papulosum cyprini (EPC) cell line from carp, Cyprinus carpio. Ann. Virol. (Inst. Pasteur) 134: 207-220

Halder, M., Ahne, W (1988). Freshwater crayfish Astacus astacus - a vector for infectious pancreatic necrosis virus (IPNV). Dis. aquat. Org. 4: 205-209

McAllister, P. E. (1979). Fish viruses and viral infections. In: Fraenkel-Conrat, H., Wagner, R. R. (eds.) Comprehensive virology Vol. 14. Plenum Press, New York, p. 401-470

Moewus-Kobb, L. (1965). Studies with IPN virus in marine hosts. Ann. N. Y. Acad. Sci. 126: 328-342

Mulcahy, D., Bauersfeld, K. (1983). Effect of loading density of sockeye salmon, Oncorhynchus nerka (Walbaum), eggs in 
incubation boxes on mortality caused by infectious haematopoietic necrosis. J. Fish Dis. 6: 189-193

Mulcahy, D., Burke, J., Pascho, R., Jenes, C. K. (1982) Pathogenesis of infectious hematopoietic necrosis virus in adult sockeye salmon (Oncorhynchus nerka). Can. J. Fish. aquat. Sciences 39: 1144-1149

Mulcahy, D., Jenes, C. K., Pascho, R. (1984). Appearance and quantitation of infectious hematopoletic necrosis virus in female sockeye salmon (Oncorhynchus nerka) during their spawning migration. Archs Virol, 80: 171-181

Mulcahy, D., Pascho, R. J. (1985). Vertical transmission of infectious haematopoietic necrosis virus in sockeye salmon, Oncorhynchus nerka (Walbaum): isolation of virus from dead eggs and fry. J. Fish Dis. 8: 393-396

Mulcahy, D., Pascho, R., Batts, W. N. (1987). Testing of male sockeye salmon (Oncorhynchus nerka) and steelhead trout (Salmo gairdneri) for infectious hematopoietic necrosis virus. Can. J. Fish aquat. Science 44: 1075-1078

Mulcahy, D., Pascho, R., Jenes, C. K. (1983a). Mortality due to infectious hematopoietic necrosis of sockeye salmon (Oncorhynchus nerka) fry in streamside egg incubation. boxes. Can. J. Fish. aquat. Science 40: 1511-1516

Responsible Subject Editor-Dr T. Evelyn, Nanaimo, B.C., Canada
Mulcahy D., Pascho, R. J., Jenes, C. K. (1983b). Titre distribution patterns of infectious haematopoietic necrosis virus in ovanan fluids of hatchery and feral salmon populations. J. Fish Dis. 6: 183-188

Mulcahy, D., Pascho, R. J., Jenes, C. K. (1983c). Detection of infectious haematopoietic necrosis virus in river water and demonstration of waterborne transmission. J. Fish Dis. 6 321-330

Mulcahy, D., Wood, J. (1986). A natural epizootic of infectious haematopoietic necrosis in imported Atlantic salmon, Salmo salar L., reared in the enzootic region. J. Fish Dis. 9: $173-175$

Pfeil-Putzien, C. (1978). Experimentelle Übertragung der Frühjahrsvirämie (spring viremia) der Karpfen durch Karpfenläuse (Argulus foliaceus). Zentbl. Veterinärmed 25: $319-323$

Pfeil-Putzien, C., Baath, C. (1978). Nachweis einer Rhabdovirus-carpio-Infektion bei Karpfen im Herbst. Berl. Münchener Tierärztl. Wochenschr. 91: 445-447

Pilcher, K. S., Fryer, J. L. (1980). The viral diseases of fish: a review through 1978. Part I: Diseases of proven viral etiol ogy. CRC Crit. Rev. Microbiol. 7: 287-364

Manuscript first received: February 24, 1989

Revised version accepted: October 31, 1989 